\title{
Monoporella projecta (Cheilostomata: Bryozoa), a New Uniserial Species from the Continental Shelf and Slope of Japan
}

\author{
Shinji Arakawa \\ Seishin-Gakuen High School, 4448-5, Kyuchu Kashima, Ibaraki 314-0031, Japan \\ E-mail:aramoja@outlook.jp \\ (Received 10 December 2019; Accepted 19 April 2020) \\ http://zoobank.org/BC835306-C8B7-44C3-B766-F1D472ABE964
}

\begin{abstract}
Monoporella projecta sp. nov. from the continental shelf and slope east of the Boso Peninsula, Japan adds to the bryozoan fauna along the northwestern Pacific coast, where more than 10 species of this genus have been recorded. Colonies of this species are uniserial encrusting in growth form, and autozooids are large and much inflated with a projecting orificial rim. These colony and zooidal characteristics may be related to the deep-water environment.
\end{abstract}

Key Words: Bryozoa, Monoporella, uniserial, projected orificial rim, Japan.

\section{Introduction}

Monoporella Hincks, 1881 is a long-duration genus of cheilostomatous bryozoans, recorded from the late Cretaceous to the Recent. Thirteen living species have been assigned to this genus (Bock 2016), including six from the Aleutian Islands (Dick 2008) and three from Philippine region (Canu and Bassler 1929; Tilbrook 2006). Dick (2008) noted that the high diversity of Monoporella in the Aleutian archipelago might represent either a relict of past high diversity occurring broadly around the North Pacific rim, or a local radiation restricted to the western Aleutians.

A number of different Monoporella species also occur in Japan. Fossil material from Miocene to Pleistocene deposits in Japan have been reported as Monoporella fimbriata Canu and Bassler, 1929 (Sakakura 1935; Kataoka 1961; Hayami 1970, 1975, 1976; Arakawa 1995), although these identifications need reexamination (Dick 2008). Monoporella specimens from Japan studied by Harmer (1926) were re-examined by Tilbrook (2006), who commented that they represent two species distinct from M. nodulifera (Hincks, 1881) and M. fimbriata. Finally, Ostrovsky and Taylor (2005) described one more unnamed Recent species from Okinawa, Japan (as Monoporella sp. 1).

In this study, I report from Japan a species of Monoporella that forms uniserial encrusting colonies. It may contribute to the study of evolution in this genus around the North Pacific.

\section{Materials and methods}

All of the study material came from the research expedition Hakurei-Maru cruise GH80-2 (Geological Survey of Japan) in 1980. Three sampling stations ranged from 144 to $350 \mathrm{~m}$ in depth on the continental shelf and slope east of the Boso Peninsula, Japan (Table 1). A Smith-McIntyre grab sampler was used at two stations (St. 1709 and 1734), and a chain-bag dredge was employed at one station (St. 1715).

Colonies and fragments of Monoporella species were picked from dried seafloor deposits under a stereoscopic microscope, and were cleaned in water or a hydrogen peroxide solution. For SEM, specimens were mounted on aluminum stubs with adhesive tape. Some were coated with Pt-Pd in a sputter coater (Model E-102, Hitachi) and observed with a Hitachi Model S-2400 scanning electron microscope at the Department of Earth Science, Faculty of Sciences, Chiba University. Other specimens were coated with $\mathrm{Au}$ in an ion coater (model SC-701AT, Sanyu Denshi) and observed with a JEOL Model JSM-5310 microscope at the National Museum of Nature and Science, Tsukuba.

Zooidal characters were measured from SEM images

Table 1. Location and bottom sediments of sampling stations (Honza and Miyazaki 1984; Nishimura 1984).

\begin{tabular}{cllll}
\hline Station No. & \multicolumn{1}{c}{ Latitude } & \multicolumn{1}{c}{ Longitude } & Depth $(\mathrm{m})$ & \multicolumn{1}{c}{ Bottom sediments } \\
\hline 1709 & $35^{\circ} 14.02^{\prime} \mathrm{N}$ & $140^{\circ} 45.20^{\prime} \mathrm{E}$ & 144 & sand and gravel \\
1715 & $35^{\circ} 54.80^{\prime}-55.35^{\prime} \mathrm{N}$ & $140^{\circ} 22.80^{\prime}-23.08^{\prime} \mathrm{E}$ & $303-350$ & medium sand and rock \\
1734 & $35^{\circ} 03.13^{\prime} \mathrm{N}$ & $140^{\circ} 26.99^{\prime} \mathrm{E}$ & 155 & medium sand \\
\hline
\end{tabular}



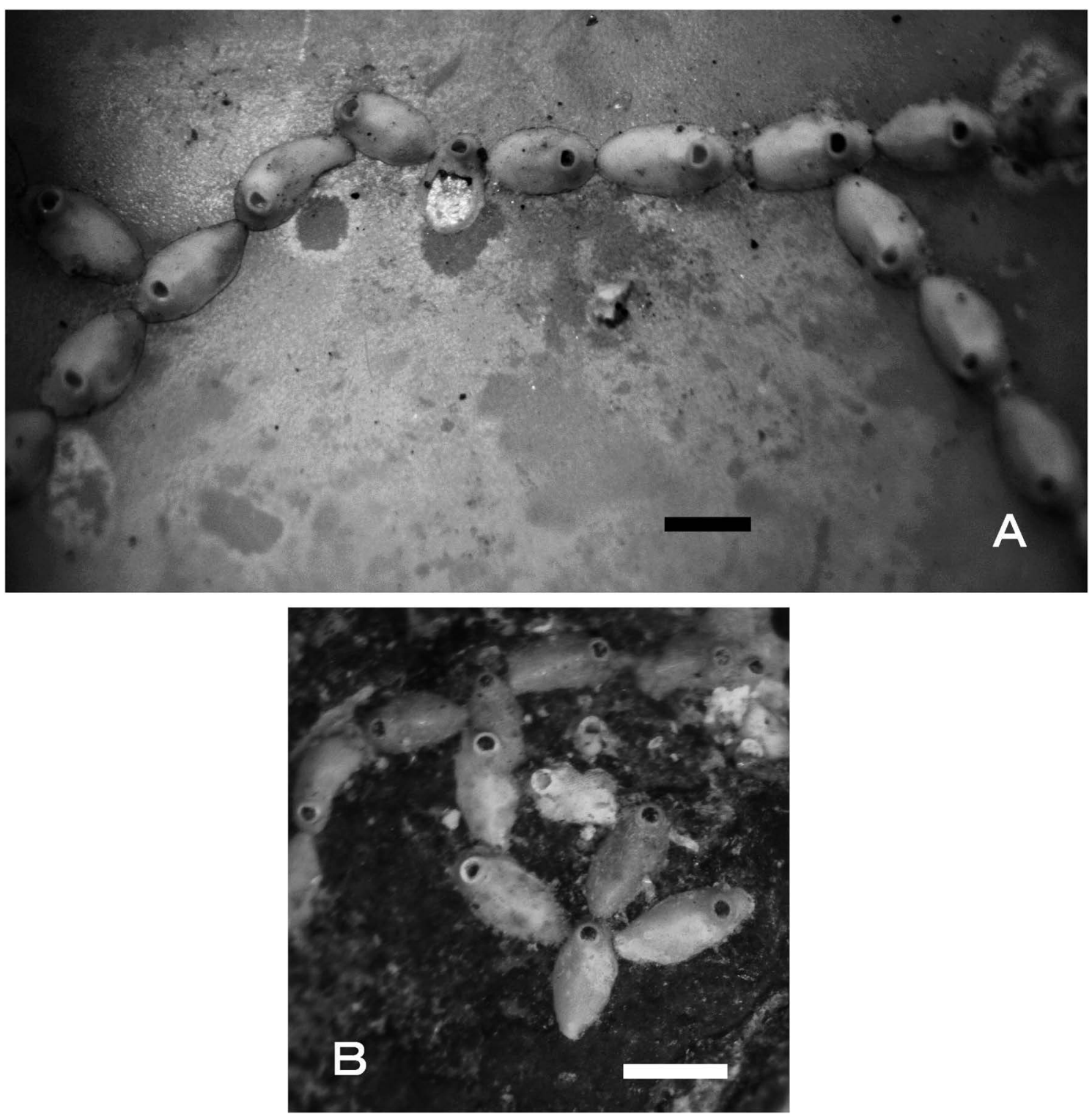

Fig. 1. Colonies of Monoporella projecta sp. nov. A, holotype, NMNS PA 16855; B, paratype, NMNS PA 18451A. Scale bars: $1 \mathrm{~mm}$.

taken at about $360 \times, 480 \times$, or $1700 \times$ magnification. Measurements (in millimeters) are presented as the range, followed by the arithmetic mean and standard deviation. Sample sizes (n) are given as the number of zooids from which a character was measured, followed by the number of colony fragment from which measurements were taken. Abbreviations used for characters measured are as follows: ZL, autozooid length; ZW, autozooid width; OrL, orifice length; OrW, orifice width.

Type material and other specimens examined in this study are deposited in the National Museum of Nature and Science, Tsukuba (collection code NMNS PA). Additional specimens examined are deposited in the collection of the science laboratory of Seishin-Gakuen, Kashima City, Ibaraki, Japan (collection code SGBC).
Order Cheilostomata Busk, 1852

Suborder Flustrina Smitt, 1868

Superfamily Microporoidea Hincks, 1882

Family Monoporellidae Hincks, 1882

Genus Monoporella Hincks, 1881

Diagnosis. Colony encrusting or erect. Frontal wall cryptocystal, granular, perforated, raised medially in general, with a pair of opesiules at the distal corners of cryptocyst. Lateral and proximal gymnocyst absent. Oral and lateral rim raised. Opesia reduced, coincident with the operculum. Oral spines present or absent. Avicularia absent. Ovicell large, spinocystal, with longitudinal costae, slit-like foramina, small pores and lateral windows. Basal pore-chambers present.

Type species. Haploporella nodulifera Hincks, 1881. 

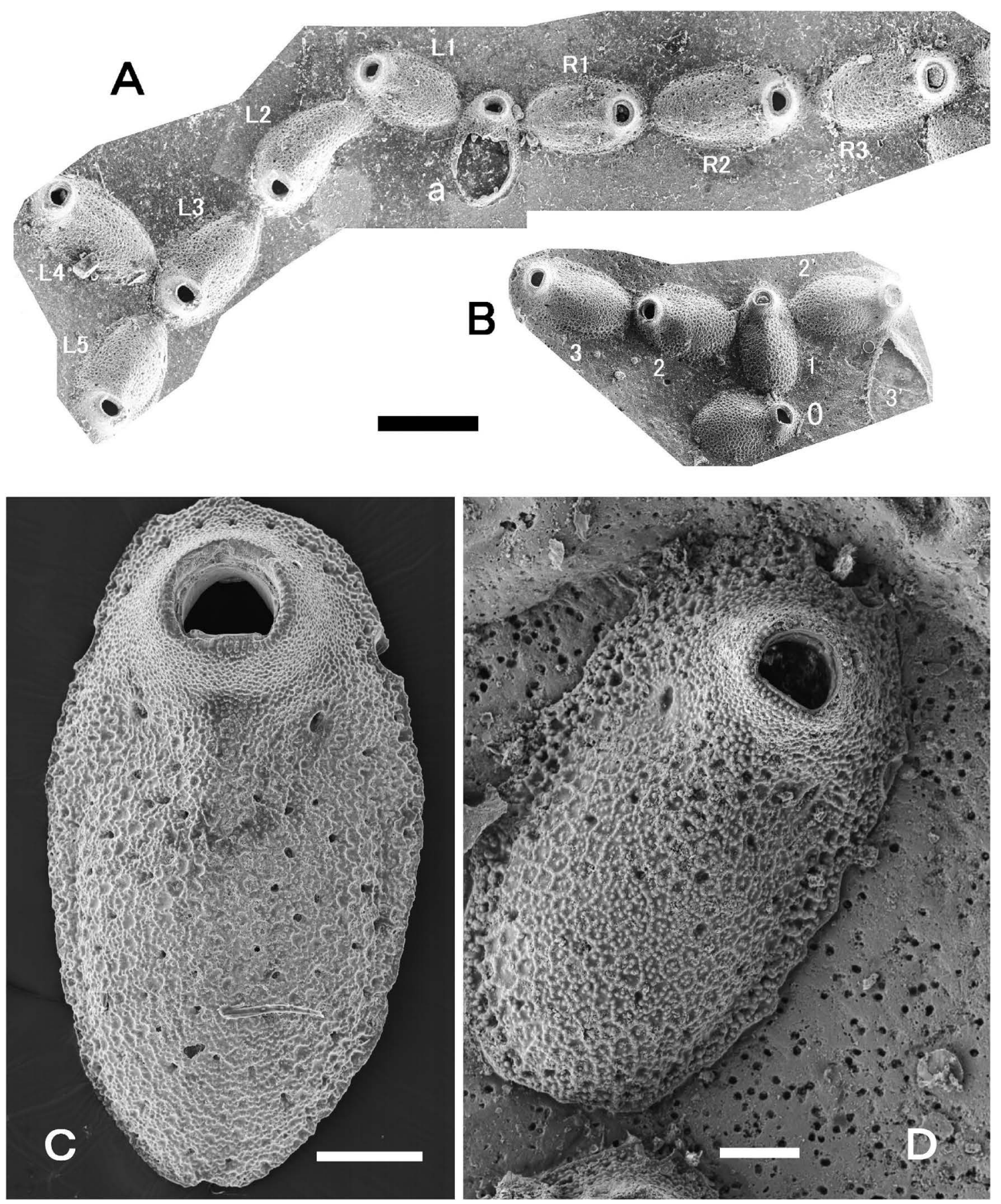

Fig. 2. Autozooids. A, holotype, NMNS PA 16855, ancestrulae "a" and subsequent zooids; B, paratype, NMNS PA 16857, ancestrulae "0" and subsequent zooids; C, zooid "L4" in A, separated from the substrate by cleaning; D, zooid " 3 " in B, moved from the original position. Scale bars: $1 \mathrm{~mm}$ in $\mathrm{A}, \mathrm{B}$, and $200 \mu \mathrm{m}$ in C, D.

Monoporella projecta sp. nov.

(Figs 1-4)

Monoporella sp.: Arakawa 1999: 57, pl. 2, fig. D.

Materials examined. Holotype: NMNS PA 16855 (on a bivalve, with separated zooids from the same colony), Station 1734, Hakurei-Maru cruise GH-80-2. Paratypes: NMNS PA 16857 (on a fragment of molluscan shell), and 18451A (on a stone, not coated with metal), Station 1734, HakureiMaru cruise GH-80-2. Other materials: NMNS PA 16856 (on a fragment of coral, not coated with metal), Station 1715, Hakurei-Maru cruise GH80-2; NMNS PA 18451B (opercula from 18451A), Station 1734, Hakurei-Maru cruise GH-80-2; NMNS PA 18452, SGBC-0379 and -0380 (all on fragments of molluscs), Station 1734, Hakurei-Maru cruise GH-80-2.

Diagnosis. Colony encrusting, uniserial. Frontal cryptocyst inflated, higher than low mural rim, showing tessellate surface, with scattered pores and a pair of small opesiules. Orificial rim highly projecting. Oral spines absent.

Etymology. The specific name comes from the Latin pro- 


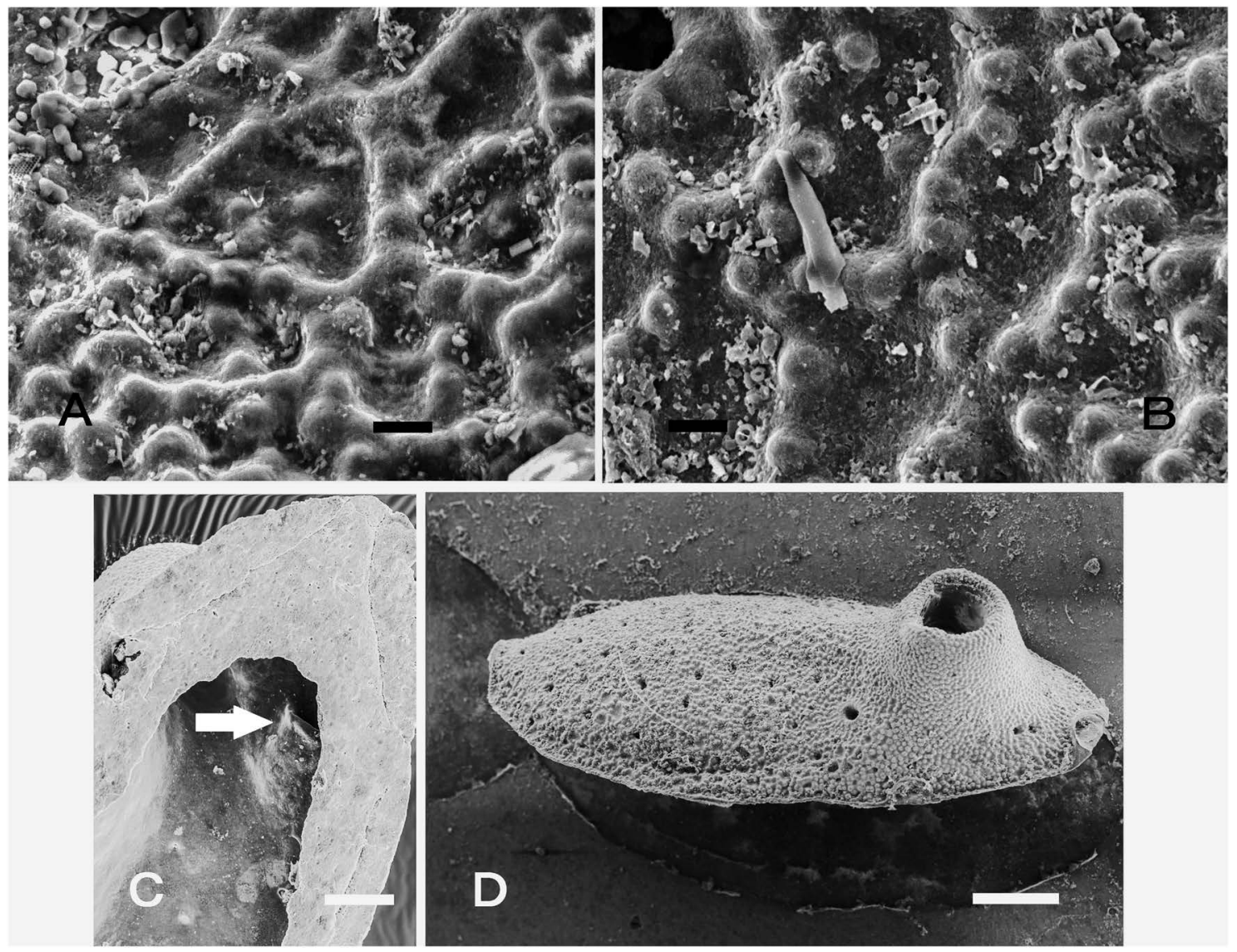

Fig. 3. Autozooids of holotype. A, close-up of frontal cryptocyst and orificial rim (lower-left), zooid "a" in Fig. 2A; B, close-up of frontal cryptocyst, zooid "R3" in Fig. 2A; C, inner side of frontal wall with a tube structure connecting an opesiule (arrow), basal wall broken; D, zooid of the lower-right row in Fig. 1A, moved from the original position. Scale bars: $20 \mu \mathrm{m}$ in A, B and $200 \mu \mathrm{m}$ in C, D.

jectus, referring to the highly projecting orificial rim.

Measurements (in mm). NMNS PA 16855, 16857 and 18452; SGBC-0379 and -0380. Autozooids (24, 4): ZL, 0.99-

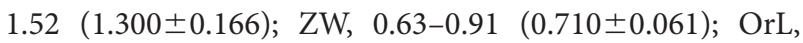

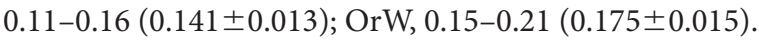

Description. Colony encrusting, uniserial; zooids generally budding one or two zooids, rarely three (Figs 1, 2A, B). Zooids elliptical, much inflated. Lateral wall very low, with pair of large communication pores laterally and one distally. Frontal wall cryptocystal, inflated above low mural rim, finely granulated; granules aligned to form reticulum of narrow ridges (Fig. $3 \mathrm{~A}, \mathrm{~B}$ ), and perforated with scattered pores; median carina sometimes observed (Fig. 2C, D); interior of frontal wall nearly smooth, with tube structure connecting small opesiules (Fig. 3C). Orifice semicircular, with straight or slightly concave proximal border, bearing small shelf in each proximo-lateral corner, sometimes with a pair of round condyles; vestibular arch well-developed, crenulated, often boomerang-shaped inside (Fig. 4A, B). Orificial rim highly projecting (Fig. 2D), about $0.3 \mathrm{~mm}$ tall; its surface finely granulated, not tessellate (Fig. 3D). Oral spines absent. Operculum black; outer surface smooth, not pitted; inner surface with thin central area and proximolateral crests for attachment of occlusor muscles (Fig. 4C, D). Ovicell not found. Avicularia absent. Ancestrulae resembling subse- quent autozooids, not so small (zooid "a" in Fig. 2A, zooid "0" in Fig. 2B).

Distribution. Presently known only from the eastern continental shelf and slope of the Boso Peninsula, Japan. The bathymetrical range is from $144 \mathrm{~m}$ to $350 \mathrm{~m}$ in depth.

Remarks. This species is characterized by the uniserial colony form, the highly inflated cryptocyst and the projecting orificial rim.

It has a smooth operculum in common with all of six Monoporella species from the Aleutian Islands (Dick 2008), and four of which (Monoporella flexibila Dick, 2008, M. elongata Dick, 2008, M. ellefsoni Dick, 2008, M. aleutica Dick, 2008) also lack oral spines. Among these, M. flexibila is most similar to M. projecta in having a low mural rim and in the obscurity of the marginal boundary of cryptocyst, especially in the initial encrusting portion of the colony.

The frontal wall of Monoporella projecta resembles the tessellate cryptocyst in M. flexibila and M. elongata, but the concavities in the cryptocyst of this species are shallower and broader than in the latter two species, and the bottom of each concavity is also generally granulated (Figs 2D, 3A). In addition, the surface of the orificial rim is not pitted in M. projecta. 

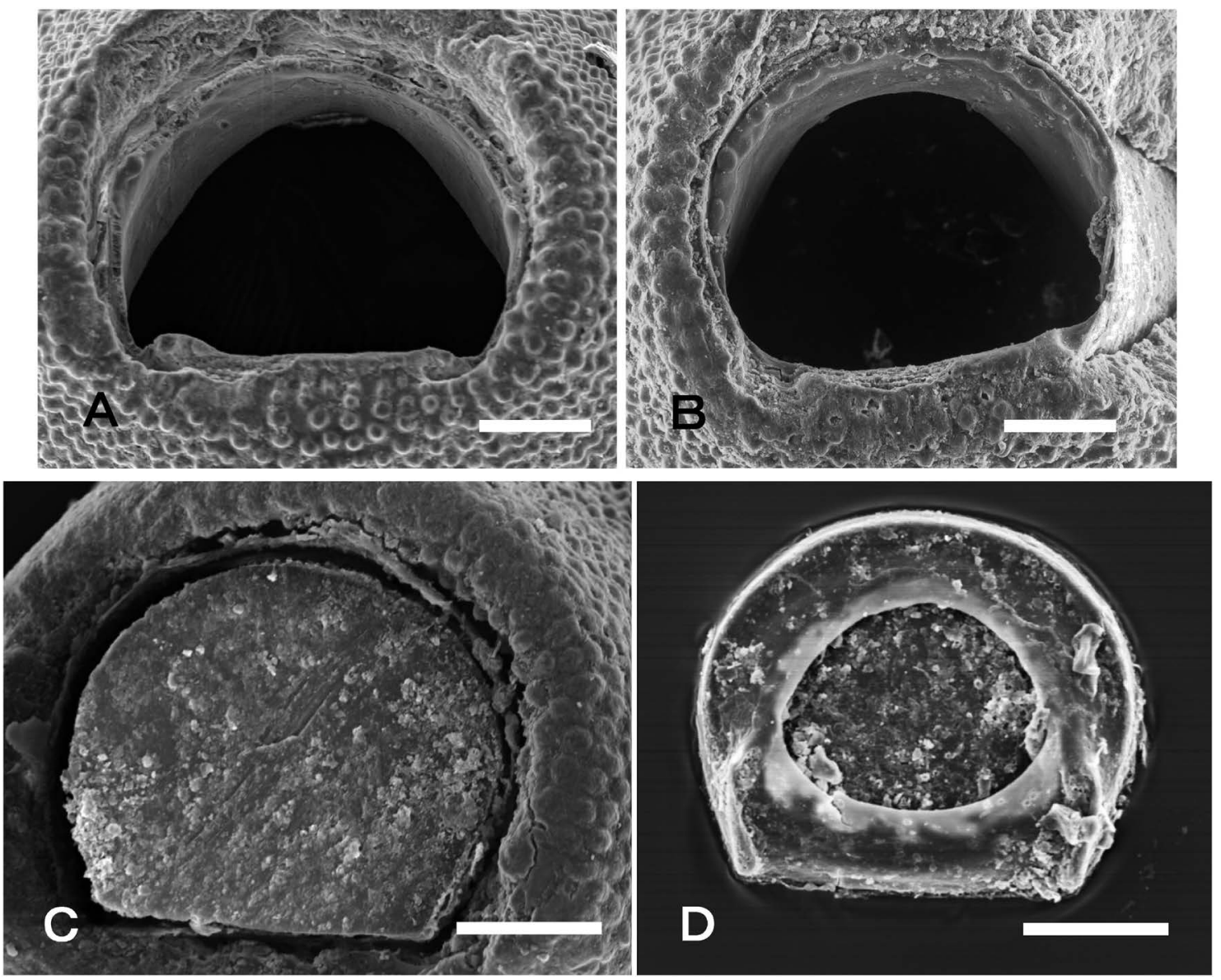

Fig. 4. Orifice and operculum. A, orifice of zooid L4 in Fig. 2A; B, orifice of one zooid of the lower-right row in Fig. 1A; C, outer surface of operculum, NMNS PA 18451B; D, inner surface of operculum, NMNS PA 18451B. Scale bars: $50 \mu \mathrm{m}$.

\section{Discussion}

Monoporella projecta sp. nov. increases the known diversity of Monoporella along the northwestern Pacific coast. Including Aleutian species, some of which show similar characteristics of the frontal wall.

Several species of Monoporella bearing an inflated frontal cryptocyst occur in the northwestern Pacific. It is very conspicuous in $M$. flexibila and $M$. projecta. Although the phylogeny is not clear, it is noteworthy that Monoporella sulcoecia Kataoka, 1961 from the Pleistocene Ryukyu Limestone also has an inflated cryptocyst and low mural rim. A highly inflated cryptocyst is also evident in the Cretaceous Monoporella convexa (Canu, 1911) from Argentina, but the cryptocyst (except for the median carina) is lower than the mural rim in most Monoporella species.

In addition, the tessellate surface of cryptocyst in Monoporella has been also observed only in species from the northwestern Pacific Ocean, including Japan.

Scholz (1991) described an ancestrula of a Monoporella species (identified as M. nodulifera) in which the proximal part of the cryptocyst is apparently tessellate. This Philippine species differs from $M$. projecta in having oral spines and a pitted operculum. Another example is Monoporella sp. 1 in Ostrovsky and Taylor (2005) from Okinawa, Japan, showing a cryptocyst with somewhat deep concavities and a finely granulated orificial rim, and bearing two to six oral spines.

Tilbrook (2006) re-examined Harmer's (1926) Siboga specimens, and referred to two Monoporella species from Japan. He identified one of them lacking oral spines and a pitted operculum as Monoporella sp. from Alaska in Taylor and McKinney (2002), i.e., Monoporella sp. 2 in Ostrovsky and Taylor (2005). This species was named Monoporella elongata by Dick (2008). If the conclusions of Tilbrook (2006) and Dick (2008) are correct, three Monoporella species with a tessellate cryptocyst, including $M$. projecta, have been recorded in Japan.

On the other hand, the characteristics of Monoporella projecta may be related to the deep water environment.

Among cheilostomes, relatively few species form uniserial encrusting colonies, except in some families such as Aeteidae, Electridae and Hippothoidae. Monoporella projecta differs from species in these families in numerous characteristics, especially zooids lacking cauda. Bishop (1989) termed such non-caudate species "category 1 of uniserial runners".

Some other species have similar uniserial colonies and zooids, e.g., Thalamoporella linearis Canu and Bassler, 1929 from $161 \mathrm{~m}$ in depth near Hong Kong; Microporella lineata Canu and Bassler, 1929 from $192 \mathrm{~m}$ in the Philippines; and Psilopsella uniseriata Canu and Bassler, 1927 from 37-192 m 


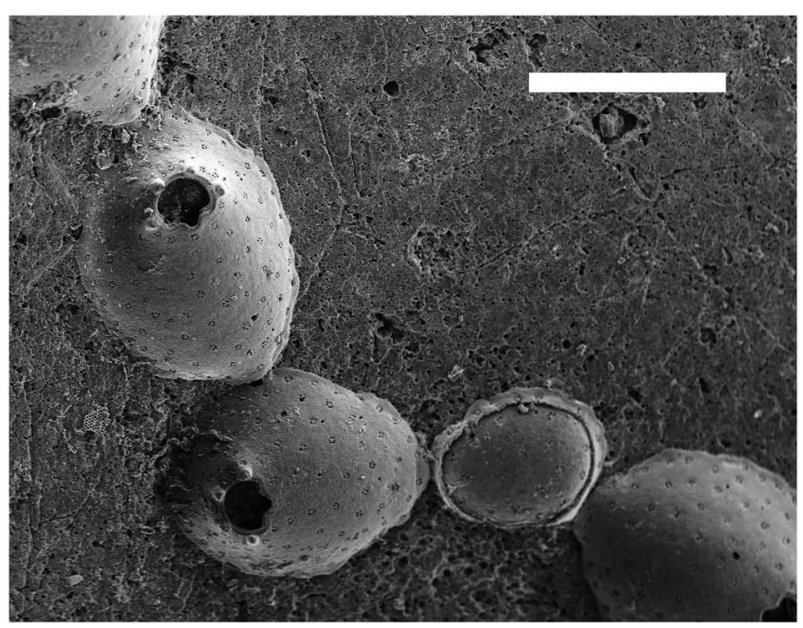

Fig. 5. Hippothoa connata Ortmann, 1890, encrusting the same substrate (a molluscan shell) as Monoporella projecta, NMNS PA 18452. Scale bar: $500 \mu \mathrm{m}$.

in the Philippines. Microporella lineata was also recorded from the Kermadec Ridge of New Zealand (Gordon 1984), and this species was found with another uniserial species Nimba terraenovae (Powell, 1967) at the same sampling stations, K826, 840, 857 and 872 (165-490 m in depth). Monoporella projecta was also observed with another uniserial species Hippothoa connata Ortmann, 1890 [Ortmann (1890: 52, taf. IV, fig. 7); reported as Cribellopora connata in Arakawa (1999)] at the same locality, Station 1734 of the Hakurei-Maru cruise GH-80-2 (155 $\mathrm{m}$ in depth), and these two encrust the same substrate (a molluscan shell) in the case of NMNS PA 18452 (Fig. 5).

Large zooid and project orificial rim of Monoporella projecta may suggest a more elevated position of lophophores that may probably reinforce the feeding current (Okamura et al. 2001). However, the biological background of this type of colony and zooidal form in the deep-water environment is not clear at the present time (see Berning et al. 2017).

\section{Acknowledgments}

I am grateful to Professor Matthew H. Dick of Hokkaido University for his critical advice on the manuscript. I also thank Dr Tomoki Kase, Dr Yasunari Shigeta and Dr Takuma Haga National Museum of Nature and Science (Tsukuba) for permission to use the SEM and also for cataloging and storing the study material in the museum.

\section{References}

Arakawa, S. 1995. Bryozoan Fauna in the Jizodo Formation (Pleistocene), Boso Peninsula, Honshu, Japan. Natural History Research 3: 75-110.

Arakawa, S. 1999. A preliminary report on cheilostomatous bryozoans from the coast and the eastern continental shelf of the Boso Peninsula. Bulletin of Seishin-Gakuen 14: 43-107. [In Japanese]
Berning, B., Harmelin, J.-G., and Bader, B. 2017. New Cheilostomata (Bryozoa) from NE Atlantic seamounts, islands, and the continental slope: evidence for deep-sea endemism. European Journal of Taxonomy 347: 1-51

Bishop, J. D. D. 1989. Colony form and the exploitation of spatial refuses by encrusting Bryozoa. Biological Reviews 64: 197-218.

Bock, P. E. 2016. Recent and Fossil Bryozoa. Monoporella Hincks, 1881. Available at http://bryozoa.net/cheilostomata/monoporellidae/ monoporella.html (26 August 2016).

Busk, G. 1852: Catalogue of Marine Polyzoa in the Collection of the British Museum, I. Trustees of the British Museum (Natural History), London, 54 pp, 68 pls.

Canu, F. and Bassler, R. S. 1929. Bryozoa of the Philippine Region. U.S. National Museum Bulletin 100 (9): i-xi+1-685.

Dick, M. H. 2008. Unexpectedly high diversity of Monoporella (Bryozoa: Cheilostomata) in the Aleutian Islands, Alaska: taxonomy and distribution of six new species. Zoological Science 25: 36-52.

Gordon, D. P. 1984. The marine fauna of New Zealand: Bryozoa: Gymnolsemata from the Kermadec Ridge. New Zealand Oceanographic Institute Memoir 91: 1-198.

Harmer, S. F. 1926. The Polyzoa of the Siboga Expedition, Pt.2. Cheilostomata Anasca. Siboga-Expeditie 28b: i-viii+181-501, pls 13-34.

Hayami, T. 1970. Miocene Bryozoa from southwest Hokkaido, Japan. Transactions and Proceedings of the Palaeontological Society of Japan (New Series) 79: 316-336.

Hayami, T. 1975. Neogene Bryozoa from northern Japan. Science Reports of the Tohoku University, 2nd Series (Geology) 45: 83-126, pls $13-19$.

Hayami, T. 1976. Cheilostomatous Bryozoa from the Moniwa Formation. Saito Ho-on Kai Museum Research Bulletin 44: 39-51.

Hincks, T. 1881. Contribution towards a general history of the marine Polyzoa. VI. Polyzoa from Bass's Straits. VII. Foreign Membraniporina (third series). VIII. Foreign Cheilostomata (Miscellaneous). Annals and Magazine of Natural History, 5th Series 8: $1-14,122-136$, pls $1-5$.

Hincks, T. 1882. Contribution towards a general history of the marine Polyzoa. IX. Foreign Cheilostomata (Miscellaneous). Annals and Magazine of Natural History, 5th Series 9: 116-126, pl. 5.

Honza, E. and Miyazaki, T. 1984. Outline of Research Cruise. Pp. 1-19. In: Miyazaki, T. and Honza, E. (Eds) Geological Investigation of the Tohoku and Ogasawara Arcs April-June 1980 (GH80-2 and 3 Cruises), Cruise Report 19. Geological Survey of Japan, Tsukuba.

Kataoka, J. 1961. Bryozoan fauna from the "Ryukyu Limestone" of Kikai-jima, Kagoshima Prefecture, Japan. Science Report of the Tohoku University, Second Series (Geology) 32: 213-272, pls 25-37.

Nishimura, A. 1984. Bottom sampling and photographing on the southeastern offshore of the Boso Peninsula. Pp. 54-66. In: Miyazaki, T. and Honza, E. (Eds) Geological Investigation of the Tohoku and Ogasawara Arcs April-June 1980 (GH80-2 and 3 Cruises), Cruise Report 19. Geological Survey of Japan, Tsukuba.

Okamura, B., Harmelin, J.-G., and Jackson, J. B. C. 2001. Refuses revisited. Enemies versus flow and feeding as determinants of sessile animal distribution and form. Pp. 61-93. In: Jackson, J. B. C., Lidgard, S., and McKinney, F. K. (Eds) Evolutionary Patterns. Growth, Form, and Tempo in the Fossil Record, The University of Chicago Press, Chicago and London.

Ortmann, A. E. 1890. Die Japanische Bryozoenfauna. (Bricht über die von Herrn Dr. L. Döderlein im Jahre 1880-81 gemachten Sammlungen). Archiv für Naturgeschichte 56 (1): 1-74, taf. 1-4.

Ostrovsky, A. N. and Taylor, P. D. 2005. Brood chambers constructed from spines in fossil and Recent cheilostome bryozoans. Zoological Journal of the Linnean Society 144: 317-361.

Sakakura, K. 1935. Pliocene and Pleistocene Bryozoa from the Boso Peninsula (I). 1. Bryozoa of the Dizôdô Beds. Journal of the Fac- 
ulty of Science of the Imperial University of Tokyo. Section II 4: $1-48$, pls $1-7$.

Scholz, J. 1991. Die Bryozoenfauna der philippinischen Riffregion Cebu. Mitteilungen aus dem Geologisch-Paläontologischen Institut der Universität Hamburg 71: 253-403.

Smitt, F. A. 1868. Kritisk förteckning öfver Skandinaviens Hafs-Bryozoer: III. Öfversigt af Kongliga Vetenskaps-Akademiens Förhandlingar 24: 279-429, taf. 16-20.

Taylor, P. D. and McKinney, F. K. 2002. Brooding in the Cretaceous bryozoan Stichomicropora and the origin of ovicell in cheilostomes. Pp. 307-314. In: Wyse Jackson, P. N., Buttler, C. J., and Spenser Jones, M. E. (Eds) Bryozoan Studies 2001, Proceedings of the Twelfth International Bryozoology Conference, Dublin, Ireland, 16-21 July 2001. A. A. Balkema Publishers, Lisse.

Tilbrook, K. J. 2006. Santa Barbara Museum of Natural History Monographs Number 4. Studies in Biodiversity Number 3. Cheilostomatous Bryozoa from the Solomon Islands. Santa Barbara Museum of Natural History, Santa Barbara (CA), 386 pp. 